\title{
Front Matter: Volume 11278
}

, "Front Matter: Volume 11278," Proc. SPIE 11278, Ultrafast Phenomena and Nanophotonics XXIV, 1127801 (8 April 2020); doi: 10.1117/12.2567557

SPIE. Event: SPIE OPTO, 2020, San Francisco, California, United States 


\section{PROCEEDINGS OF SPIE}

\section{Ultrafast Phenomena and Nanophotonics XXIV}

\section{Markus Betz}

Abdulhakem Y. Elezzabi

Editors

2-4 February 2020

San Francisco, California, United States

Sponsored by

SPIE

Cosponsored by

Class 5 Photonics GmbH (Germany)

Published by

SPIE 
The papers in this volume were part of the technical conference cited on the cover and title page. Papers were selected and subject to review by the editors and conference program committee. Some conference presentations may not be available for publication. Additional papers and presentation recordings may be available online in the SPIE Digital Library at SPIEDigitalLibrary.org.

The papers reflect the work and thoughts of the authors and are published herein as submitted. The publisher is not responsible for the validity of the information or for any outcomes resulting from reliance thereon.

Please use the following format to cite material from these proceedings:

Author(s), "Title of Paper," in Ultrafast Phenomena and Nanophotonics XXIV, edited by Markus Betz, Abdulhakem Y. Elezzabi, Proceedings of SPIE Vol. 11278 (SPIE, Bellingham, WA, 2020) Seven-digit Article CID Number.

ISSN: 0277-786X

ISSN: 1996-756X (electronic)

ISBN: 9781510633193

ISBN: 9781510633209 (electronic)

Published by

SPIE

P.O. Box 10, Bellingham, Washington 98227-0010 USA

Telephone +1 3606763290 (Pacific Time) · Fax +1 3606471445

SPIE.org

Copyright (C) 2020, Society of Photo-Optical Instrumentation Engineers.

Copying of material in this book for internal or personal use, or for the internal or personal use of specific clients, beyond the fair use provisions granted by the U.S. Copyright Law is authorized by SPIE subject to payment of copying fees. The Transactional Reporting Service base fee for this volume is $\$ 18.00$ per article (or portion thereof), which should be paid directly to the Copyright Clearance Center (CCC), 222 Rosewood Drive, Danvers, MA 01923. Payment may also be made electronically through CCC Online at copyright.com. Other copying for republication, resale, advertising or promotion, or any form of systematic or multiple reproduction of any material in this book is prohibited except with permission in writing from the publisher. The CCC fee code is 0277$786 \mathrm{X} / 20 / \$ 18.00$.

Printed in the United States of America.

Publication of record for individual papers is online in the SPIE Digital Library.

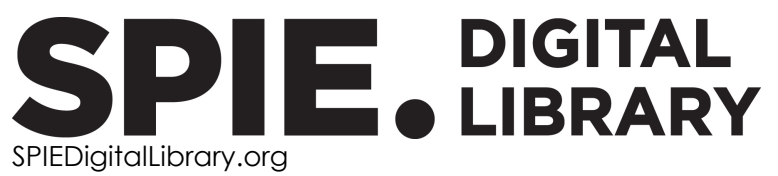

Paper Numbering: Proceedings of SPIE follow an e-First publication model. A unique citation identifier (CID) number is assigned to each article at the time of publication. Utilization of CIDs allows articles to be fully citable as soon as they are published online, and connects the same identifier to all online and print versions of the publication. SPIE uses a seven-digit CID article numbering system structured as follows:

- The first five digits correspond to the SPIE volume number.

- The last two digits indicate publication order within the volume using a Base 36 numbering

system employing both numerals and letters. These two-number sets start with 00, 01, 02, 03, 04,

05, 06, 07, 08, 09, OA, OB ... 0Z, followed by 10-1Z, 20-2Z, etc. The CID Number appears on each

page of the manuscript. 


\section{Contents}

$\begin{array}{ll}\vee & \text { Authors } \\ \text { vii } & \text { Conference Committee }\end{array}$

2D MATERIALS I

1127805 Biexcitons do not form in MoS 2 monolayers from optical pumping at 6 K [1 1278-4]

PHOTOVOLTAIC MATERIALS

11278 OA Ultrafast transient absorption spectroscopic studies of new dumbbell-shaped platinum (Pt) systems composed of "weight" and "bar" chromophores (Invited Paper) [1 1278-9]

THz SPECTROSCOPY I

$11278 \mathrm{OF}$ Terahertz lightwave control of non-equilibrium phases and collective modes in multi-band superconductors (Invited Paper) [11278-14]

$11278 \mathrm{OH} \quad$ Transient photoconductivity and photo-excited carrier dynamics in $\left(\mathrm{Bi}_{1-\mathrm{x}} \mathbf{l} \mathbf{n}_{\mathrm{x}}\right)_{2} \mathrm{Se}_{3}$ thin films [11278-16]

11278 ol Zero-valent Au, Cu, and Sn intercalation into GeS nanoribbons: tailoring ultrafast photoconductive response [11278-17]

\section{CARRIER DYNAMICS IN SEMICONDUCTORS AND NANOSTRUCTURES I}

$11278 \mathrm{OP}$ Oxygen vacancy effect on ultra-fast carrier dynamics of perovskite oxide $\mathrm{La}_{0.7} \mathrm{Sr}_{0.3 \mathrm{MnO}} \mathrm{M}_{3}$ thin films (Invited Paper) [1 1278-24]

11278 OR Pump-probe study of ultrafast response of GaAs photocathodes grown by MOCVD and MBE [11278-26]

11278 OS k•p-based multiband simulations of non-degenerate two-photon absorption in bulk GaAs [11278-27] 


\section{CARRIER DYNAMICS IN SEMICONDUCTORS AND NANOSTRUCTURES II}

11278 OT Polarization-dependent absolute-phase-corrected multidimensional coherent spectra of exciton-polaritons [1 1278-28]

1127810 Time-resolved inline digital holography for measurement of optical nonlinear properties of quantum dots on substrates [11278-35]

\section{PLASMONICS}

1127815 Resonance-enhanced transmission of surface plasmon polariton wave-packets through metalinsulator-metal nanocavities [11278-40]

ULTRAFAST OPTICAL TECHNIQUES

$112781 \mathrm{~A} \quad$ Femtosecond OPCPAs from UV to short-wave IR wavelengths for ultrafast dynamics experiments from condensed matter to atoms, molecules, and clusters [11278-45]

\section{D MATERIALS II}

11278 1C Coherent dynamics of resonantly excited excitons in monolayers of transition metal dichalcogenides (Invited Paper) [1 1278-47]

\section{POSTER SESSION}

$112781 \mathrm{M}$ Temperature dependence of interface-state-phonon-assisted carrier relaxation in CdSe quantum dots [11278-56]

iv 


\title{
Authors
}

Numbers in the index correspond to the last two digits of the seven-digit citation identifier (CID) article numbering system used in Proceedings of SPIE. The first five digits reflect the volume number. Base 36 numbering is employed for the last two digits and indicates the order of articles within the volume. Numbers start with 00, 01, 02, 03, 04, 05, 06, 07, 08, 09, OA, OB...0Z, followed by 10-1Z, 20-2Z, etc.

\author{
Alfano, Robert R., $1 \mathrm{M}$ \\ Allodi, Marco A., 05 \\ Anilao, Auddy, II, OI \\ Bartos, Miroslav, $1 \mathrm{C}$ \\ Belashov, Andrey $V_{.}, 10$ \\ Bristow, Alan D., OP, OT \\ BuB, J. H., IA \\ Cheng, C. J., 10 \\ Damian, Leticia, 0 I \\ Du, Lili, OA \\ Duan, Lingze, OR \\ Engel, Gregory S., 05 \\ Gao, Hui, 05 \\ Golz, T., 1A \\ Grguraš, I., IA \\ Hannes, W.-R., OS \\ Holcomb, M. B., OP \\ Ichiji, Naoki, 15 \\ Jakubczyk, Tomasz, 1C \\ Jani, Hemang, OR \\ Kasprzak, Jacek, 1C \\ Koski, Kristie J., 01 \\ Kubo, Atsushi, 15 \\ Kushnir, Kateryna, $\mathrm{OH}$, OI \\ Langbein, Wolfgang, $1 \mathrm{C}$ \\ Law, Stephanie, $\mathrm{OH}$ \\ Liang, Runhui, $\mathrm{OA}$ \\ Lloyd, Lawson T., 05 \\ Mazuski, Richard, 05 \\ Meier, T., OS \\ Mootz, Martin, OF \\ Mottaghi, N., OP \\ Mudiyanselage, Din H., OF \\ Mujid, Fauzia, 05 \\ Nogajewski, Karol, 1C \\ Park, Jiwoong, 05 \\ Paul, Jagannath, OT \\ Perakis, llias E., OF \\ Petrov, Nikolay V., 10 \\ Phillips, David Lee, OA \\ Potemski, Marek, 1C \\ Prandolini, M. J., 1A \\ Qian, Yunsheng, OR \\ Riedel, R., 1A \\ Scarpelli, Lorenzo, 1C \\ Schulz, M., 1A \\ Shi, Teng, $\mathrm{OH}, \mathrm{Ol}$ \\ Ting, Po-Chieh, 05 \\ Titova, Lyubov $\vee ., \mathrm{OH}, \mathrm{Ol}$
}

Trappen, R., OP

Vaswani, Chirag, OF

Wahlstrand, Jared K., OT

Wang, Jigang, OF

Wang, Lili, 05

Wang, Zhengtianye, $\mathrm{OH}$

Wood, Ryan E., 05

Xie, Saien, 05

Xiong, Wenjuan, OA

Yang, $\mathrm{XU}, \mathrm{OF}$

Yousefi, S., OP

Zhang, Shengkun, 1M

Zhang, Yijun, OR

Zhou, Rui, OR 
Proc. of SPIE Vol. 11278 1127801-6

\section{Downloaded From: https://www.spiedigitallibrary.org/conference-proceedings-of-spie on 26 Apr 2023
Terms of Use: https://www.spiedigitallibrary.org/terms-of-use}




\section{Conference Committee}

Symposium Chairs

Sailing He, KTH Royal Institute of Technology (Sweden) and Zhejiang University (China)

Yasuhiro Koike, Keio University (Japan)

Symposium Co-chairs

Connie J. Chang-Hasnain, University of California, Berkeley (United States)

Graham T. Reed, Optoelectronics Research Center, University of Southampton (United Kingdom)

Program Track Chairs

James G. Grote, Photonics Engineering Consultant (United States)

Shibin Jiang, AdValve Photonics, Inc. (United States)

Conference Chairs

Markus Betz, Technische Universität Dortmund (Germany)

Abdulhakem Y. Elezzabi, University of Alberta (Canada)

Conference Program Committee

Alan D. Bristow, West Virginia University (United States)

Keshav Dani, Okinawa Institute of Science and Technology Graduate University (Japan)

Jeff Davis, Swinburne University of Technology (Australia)

Kimberley C. Hall, Dalhousie University (Canada)

Rupert Huber, Universität Regensburg (Germany)

Robert A. Kaindl, Lawrence Berkeley National Laboratory (United States)

Dai-Sik Kim, Seoul National University (Korea, Republic of)

Xiaoqin Li, The University of Texas at Austin (United States)

Christoph Lienau, Carl von Ossietzky Universität Oldenburg (Germany)

James Lloyd-Hughes, The University of Warwick (United Kingdom)

Torsten Meier, Universität Paderborn (Germany)

Frank J. Meyer zu Heringdorf, Universität Duisburg-Essen (Germany)

Walter Pfeiffer, Universität Bielefeld (Germany)

Pascal Ruello, Le Mans Université (France)

Volker J. Sorger, The George Washington University (United States)

Fabrice Vallee, Institut Lumière Matière (France) 
Kam Sing Wong, Hong Kong University of Science and Technology (Hong Kong, China)

\section{Session Chairs}

1 2D Materials I

Markus Betz, Technische Universität Dortmund (Germany)

2 Metamaterials

Matt W. Graham, Oregon State University (United States)

3 Photovoltaic Materials

Sarah Houver, ETH Zurich (Switzerland)

4 THz Spectroscopy I

Frederic Laquai, King Abdullah University of Science and Technology (Saudi Arabia)

5 THz Spectroscopy II

Abdulhakem Y. Elezzabi, University of Alberta (Canada)

6 Carrier Dynamics in Semiconductors and Nanostructures I

Alan D. Bristow, West Virginia University (United States)

7 Carrier Dynamics in Semiconductors and Nanostructures II

Rudolf Bratschitsch, Westfälische Wilhelms Universität Münster (Germany)

8 Plasmonics

Simon Thibault, Université Laval (Canada)

9 Ultrafast Optical Techniques

Giulio N. Cerullo, Politecnico di Milano (Italy)

10 2D Materials II

Alexander Steinhoff, Universität Bremen (Germany)

11 Perovskites

Tomasz Jakubczyk, Universität Basel (Switzerland) 